\title{
The Trend of Arabic and Islamic Education in Nigeria: Progress and Prospects
}

\author{
Kamil Adeleke Adeyemi \\ Department of Religious Studies, Faculty of Arts, Ekiti State University, Ado-Ekiti, Nigeria \\ Email: aadeleke21@gmail.com,yemikamil@yahoo.com
}

Received 1 May 2016; accepted 3 June 2016; published 7 June 2016

Copyright (C) 2016 by author and Scientific Research Publishing Inc.

This work is licensed under the Creative Commons Attribution International License (CC BY). http://creativecommons.org/licenses/by/4.0/

(c) (7) Open Access

\begin{abstract}
Islam came to the place now known as Nigeria several centuries ago. Hence, before English Language, Arabic Language and Islamic education have dominated many cultures of Nigeria. However, government recognition of this has been very slow. This paper documents how Arabic education came to Nigeria and its development. The paper particularly analyses the current problems that this language and religious education is encountering at present, including, lack of unified syllabus, lack of qualified teachers, lack of relevant texts, low enrolment of students, the lackadaisical attitude of few students and the uncared attitude of even the government. The methods adopted are historical and analytical. Suggestions were made on how to develop Arabic and Islamic education in Nigeria.
\end{abstract}

\section{Keywords}

\section{Arabic, Language, Islam, Education, Nigeria}

\section{Introduction}

For centuries, scholars have realised that Arabic as a language and Islam as a religion have contributed substantially to world civilization, culture and education. It was Islam that revived the human pursuit of science and it was through the Arab, not the Roman that the modern world achieved light and power through science. Fafunwa (1995: pp. 50-72) explains that in the ninth and tenth centuries, the Muslims compiled great lexicons and developed philological learning in Islam. At least a century before the western world thought of establishing higher centres of learning, the Muslims world had established such institutions in some cities such as Basra, Kufa, Baghdad, Cairo and Cordova. These began as religious schools located in Mosques, and later developed into universities. Timingham (1959: p. 30) also notes that Arabic as a language contributed to an understanding of the early history and civilization of West Africa. This paper dwells on the following items: 
1) Introduction;

2) Emergence of Arabic and Islamic Scholarship in Nigeria;

3) The Development of Arabic and Islamic Education in Nigeria;

4) Problems facing Arabic and Islamic Education in Nigeria;

5) The Progress made on Arabic and Islamic Education;

6) Conclusion.

\section{Emergence of Arabic and Islamic Scholarship in Nigeria}

If anything is to be written on Arabic and Islamic education in Nigeria, few lines must be written on the scholars who broughtit to Nigeria and where it came from. Fafunwa (1995: pp. 50-72) touches this area that Islam was brought to Hausaland in the early fourteenth century by traders and scholars from Mali and other places of West Africa. During the reign of Yaqub (1452 C.E.-1463 C.E.), some Fulani scholars migrated to Kano, bringing with them books on Islamic theology and jurisprudence. It was during this period that Muslim scholars from Timbuktu came to Kano to teach and preached Islam. Al-Maghili, a famous scholar, later went to Katsina which had also become a centre of Arabic and Islamic learning during the fifteenth century. Many scholars emerged from this centre.

They organised themselves into a sort of guild, and a master would grant a recognised certificate (ijazah) to those students who satisfactorily passed the prescribed courses under him. This system continued until the coming of the British to Nigeria. It was this Arabic and Islamic education which gave cultural prestige to Islam.

\section{The Development of Arabic and Islamic Education in Nigeria}

Davidson (1990: p. 61) states that the history of the teaching of Arabic throughout the Islamic world, particularly in the non-Arab world, has been the history of the spread of Islam. This is one of the reasons why the elementary Arabic schools in Nigeria were called Qur'anic schools, and both Arabic and Islam were taught simultaneously. Thus two types of Qur'anic schools developed in Nigeria are tablet-school and higher school. The first school is meant for beginners while the higher school embraces all aspects of Arabic and Islamic Studies.

The teaching and learning of the Qur'an and the Arabic language started in Northern Nigeria where the teachers in the early stage depended for their living on charity. Alikali (1967: p. 11) lamented that the noble principle, which was successfully applied in the early stage of the development of Arabic and Islamic education, reduced the status of a teacher (Mucallim) to that of a mere beggar; he came to occupy socially a rather low status. He had to wander from place to place looking for charitable Muslims to patronise him and give him food and shelter. Whenever his efforts were not sufficient to procure the basic necessities of life, he had to send his pupils from door to door for charity to sustain himself and the pupils living with him.

Earlier on at the beginning of Qur'anic schools in Nigeria, they were usually found in or outside the mosque as it was done in the oldest Muslim University, Al-Azhar in Cairo. Today, thousands of these schools are to be found in Northern and Southern Nigeria, located either in mosques, private houses or premises specially built for this purpose.

In the Southern part of Nigeria, the introduction of Western oriented education was exclusively due to the efforts of the Christian missionaries. In 1853, the Reverend David Hinderer's wife, Anna, wrote in her diary about the response of Ibadan people to the western education taught at the day school. This attitude of some people in Ibadan is easily understood if we examine the curriculum of such primary schools. Pupils were taught to read the New Testament, the Catechism and the Commandments in Yoruba and to speak some words of English. Therefore, their parents were afraid that their children would be converted to Christianity by such an education (Adeyemi 1996: pp. 28-29).

National Teacher's Institute (N. T. I. 1983) states that Christian missionaries dominated the education on scene in Nigeria during the early period of western education, Muslim parents did not hide their discontent to the attitude of missionaries in winning converts through the school. Later, the colonial government in the early 1930s established several schools in response to appeal by Muslim Nigerians when many popular Muslim missionary organisations sprang up and built numerous primary and secondary schools to teach western education alongside Arabic and Islamic Studies. Some of them had built Arabic and Qur'anic schools offering courses at primary and pre-university levels.

Adeyemi (1996: pp. 28-29) states further that when the Muslim intellectuals realised the importance of the 
western type of education, in the age of industrialisation, scientific and technological advances especially in the 1950s, they felt that they were not participating enough in the administration of government. They also needed Muslim lawyers, doctors, engineers and educationists. They wanted to achieve these aims without changing their religion and culture. They felt a need to combine a sound Muslim education with an equally sound education along western lines. This caused renewed enthusiasm in Muslim circles.

Fafunwa (1995: pp. 50-72) explains that within the ranks of the orthodox Muslims, a number of organisations sprang up at the turn of twentieth century to develop western derived education within a Muslim context. One of the most dynamic and the largest of these organisations was the Ansar-ud-deen Society which was founded in Lagos in 1923. In a booklet published by the Society, it is stated that prior to the inauguration of the Society, only two or three Muslim schools were being run. The Christian missionaries on the other hand, dominated the educational life of the country, and pressure was being exerted on some of the Muslim pupils attending the Christian schools to convert to Christianity.

In 1937, the Ansar-ud-Deen Society was introduced to Ibadan and it later built schools there. Similarly, the Nawarud-Deen Society, Ahmadiyyah Movement, Jamaatul Islamiyyah, Zumratul Islamiyyah and other Muslim organisations also established primary and secondary schools in Yoruba land. Another one was the establishment of two secondary grammar schools by the Ansar-ud-deen and the Ahmadiyyah Movement in the then Mid-Western State of Nigeria (now known as Edo and Delta States). All these schools, both primary and secondary, insisted on imparting the Arabic and Islamic Education as a subject. The environment of the schools by then was kept Islamic so that Muslim children could gain western education without parents being concerned about Christian proselytization.

The condition of the twin subjects has changed today. Hassan (2015: p. 24) explains that the revision of the National Policy on Education in 2004 in tune with the Universal Basic Education witnessed the emergence of the new Primary School Curriculum suggested a minimum of three periods per week for both subjects for effective teaching.

He states further that until 2015, Islamic as well as Arabic studies have not got a desk officer in Nigerian Educational Research and Development Council, Abuja, as other subjects had. That is indeed detrimental to the progress of the subjects at that level. As regards the number of schools offering Arabic and Islamic Education and their respective locations throughout the thirty-six states including Abuja, the Federal capital territory, it is very difficult to ascertain in this research. Such a step will require a separate attention which will ultimately lead to another research work entirely.

\section{Problems Facing Arabic and Islamic Education in Nigeria}

There are many problems blocking the way of Arabic and Islam education in Nigeria. Some of them are:

\subsection{Lack of Unified Syllabus}

The syllabus in operation varies from one Arabic school to another. That is, there is no co-ordination between one school and another, especially in the South-Western Nigeria. Until recently, the National Board of Arabic and Islamic Studies (NBAIS), was brought to the South West in order to unite interested Arabic schools to have common examination and certificate called Senior Certificate of Arabic and Islamic Studies for admission into tertiary institutions as it is done in the Northern part of the country.

\subsection{Inadequacy of Qualified Teachers}

According to Abdul (1983: pp. 42-53), basic elementary knowledge of linguistics ought to be a prerequisite for anyone who wishes to specialise in the teaching of a language. Arabic especially requires this and something more: motivation. To teach or learn a language outside its native environment requires motivation and devotion. There is a dearth of qualified teachers in quantity vis-à-vis primary, secondary and tertiary institutions in many parts of the country. Besides, a great number of the few available ones lack linguistic background.

\subsection{Unavailability of Suitable Textbooks}

Most of the textbooks used in our institutions are those written for learners in environments outside Nigeria. Thus the content of the books are usually not within the students' experience. The expressions are of so high a 
standard that the students get more and more discouraged.

In most of the institutions where Arabic language and literature are taught, books, rather than the language, are taught. Textbook must have bearings to a large extent to the background and culture of the learners if they are to mean anything to them.

\subsection{Admission of the Students}

Abdul (1983: pp. 42-53) lamented that in many universities especially those situated in the Southern part of the country, a credit in English at Ordinary Level $(\mathrm{O} / \mathrm{L})$ examination is demanded. In the first instance, there are very few secondary schools in the country which offer Arabic at Senior School Education (S. S. E) level. But there are many religious institutes (Macāhid) though unrecognised by the Ministry of Education, which teach Arabic to such a standard that would compare well with the Advanced level. Many of such candidates are likely to lack the required standard in English Language. It bears down to this that such candidates who concentrated on Arabic which they usually master very well outside formal secondary education, but cannot satisfy English requirement, would not be admitted, while those who study Arabic in the formal secondary schools recognised by the Ministry of Education and who are able to satisfy the English language requirement but whose standard in Arabic is very low would manage to gain admission.

Two results will emerge from this. First, the university does not always fill the specified quota for Arabic Studies which in itself is inadequate. Secondly, the standard of many of those admitted is below the standard reached in other subjects taught at university level; as a result, the teacher have to bend back somehow to bring such students to university level.

\subsection{Lackadaisical Attitudes of the Students}

Some students of Arabic tend to become frustrated as soon as they are confronted by some difficulties the language itself presents. Their response is either dropping out, which is common, or to display alukewarm response. Among the reasons of this is lack of concrete background on the subject by the students before getting into higher institution. The remedy can come from the teacher. If the teacher is a motivated and devoted one, s/he will employ various tactics to excite and regenerate the interest of the students; but if he is anon-motivated one, s/he will just abandon the students with the problems.

\subsection{Uncared Attitudes of the Government}

In the Inspectorate Division of the Ministry of Education, there is an Inspector for every subject except Arabic. This is a sign of indifference on the part of the Government. The effective teaching will be guaranteed when the subject is adequately supervised from Inspectorate Division of the Ministry.

\section{The Progress Made on Arabic and Islamic Education}

Although there are problems, there are many ways in which the achievements are recognised from Arabic and Islamic education in Nigeria today. In the National Policy on Education of the Federal Republic of Nigeria (1983), it is allowed to study Arabic and Islamic at all levels of education which was not so before. Adeyemi (1996: pp. 28-29) sheds more light on this, that for many years back in the history of Arabic and Islamic education in Nigeria, graduates from Qur'anic schools had no future because the Qur'anic or Arabic and Islamic schools had no uniform curriculum. It was not only difficult to determine the level of attainment of the scholars, but also to fix salaries for them. These problems were removed with the establishment of the School for Arabic Studies (S. A. S.) in 1947 when programme for training Arabic and Qur'anic teachers for primary schools was started. Later, similar programmes for post-primary Qur'anic and Arabic teachers were established.

Today, many Nigerian universities such as Universities of Ilorin, Ahmadu Bello in Zaria, Ibadan, Bayero in Kano, Lagos, Sokoto, Maiduguri, Ekiti State University among others are known for their programme in offering degrees at various levels such as Bachelor of Arts (B. A.), Bachelor of Arts Education (B. A. Ed), Master of Arts (M. A.), Master of Arts Education (M. A. Ed) and Doctor of Philosophy (Ph. D) in Arabic and Islamic Studies. Likewise in most Colleges of Education, Arabic and Islamic educations are studied freely with qualified lecturers employed by the Government.

Furthermore, some colleges are established by the Government like College of Arabic and Islamic Legal 
Studies (C. A. L. L) in Ilorin while some other Islamic schools got affiliation to either universities in Nigeria here or in the Arab world and to some Colleges of education such as Oro, Ilorin and others which recognise the certificates of such Arabic schools.

Many graduates of Arabic and Islamic education system serve as judges from Kwara up to Northern States of Nigeria and in the various capacities across the nation. To buttress this fact, Canham and Ozigi (1979: p. 57) opined that to regard Islamic education in Nigeria as a sort of fossilised relic of glorious but irrelevant past is to misinterpret history.

\section{Conclusion}

In the beginning, Arabic and Islamic schools had no uniform curriculum and it was not only difficult to determine the level of attainment of scholars but also to fix salaries for them. But these problems were solved through the help of western education's positive influence when School for Arabic Studies was established in Kano in 1947. Today, many Nigerian universities offer various degrees in Arabic and Islamic Studies, and Colleges of Education on different levels liberate many Muslim scholars from their conservative behaviours towards modern education.

It is obvious that as from the colonial era till today, the Government did not accredit most of Arabic and Islamic learning centres and the Certificates awarded there cannot fetch their products white collar jobs or admission for further studies to higher institutions. This made many Muslims to consider government jobs to be highly prestigious thus leading them to abandon Arabic and Islamic education which could not qualify them or their children for such appointment unless they attend western oriented schools. To solve this problem, the Arabic schools can include English language and some of the other subjects taught in western oriented schools in their syllabuses. Also, if Muslims can encourage their children to attend the government schools where they can be taught Arabic and Islamic Studies in the primary and secondary schools levels, the problem is likely to be over.

In a nutshell, Arabic schools should modernize their academic fashion with the same of western type. There should be a unified syllabus and curriculum of studies among all Arabic schools, while dependence on foreign books should be discouraged. Doing these will help to prepare Arabic learners in the tertiary levels thereby will make it possible for the continuity of Arabic and Islamic education in the Nation's educational system.

\section{References}

Abdul, M. O. A. (1983). The Teaching of Arabic in Nigerian Universities; Problems and Prospects. Journal of the Nigerian Association of Teachers of Arabic and Islamic Studies (NATAIS), 2, 42-53.

Adeyemi, K. A. (1996) Influence of Western Education on Arabic and Islamic System of Education in Ayedaade L. G. A (pp. 28-ss29). Unpublished, P. G. D. E. Dissertation, Ilorin: University of Ilorin.

Alikali, H. A. (1967) A Note on Arabic Teaching in Northern Nigeria. Kano State, No. 3, p. 11.

Canham, P., \& Ozigi, A. (1979). An Introduction to the Foundations of Education (p. 57). Lagos: Macmillan Nigeria Publishers Ltd.

Davidson, B. (1990). Old Africa Rediscovered (p. 61). London: Gollancz.

Fafunwa, A. B. (1995). History of Education in Nigeria (pp. 50-72). London: George Allen and Unwin.

Federal Republic of Nigeria (1983). National Policy on Education (Rev. ed.). Lagos: NERDC.

Hassan, A. B. K. (2015). Islamic Education in Primary Schools: A study of North Central Geo-Political Zone of Nigeria. In B. O. Yusuf (Ed.), Nigeria Association of Teachers of Arabic and Islamic Studies (NATAIS) at 40 (pp. 17-33). Ilorin: Unilorin Press.

National Teacher’s Institute, (N. T. I.) (1983), History of Nigerian Education Module 5. Ibadan; Evans Brothers (Nigerian Publishers) Ltd.

Timingham, J. S. (1959) Islam in West Africa (p. 30). London: Oxford University Press. 